Tjalling C. Koopmans Research Institute

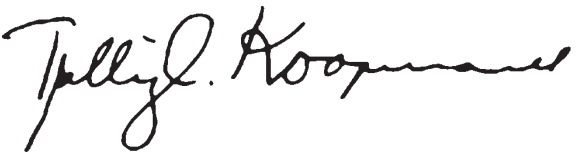

Discussion Paper Series nr: 10-05

\title{
Dual and common agency issues in international joint ventures: Evidence from China
}

Hein Roelfsema

Yi Zhang 


\section{Tjalling C. Koopmans Research Institute Utrecht School of Economics \\ Utrecht University}

Janskerkhof 12

3512 BL Utrecht

The Netherlands

telephone $\quad+31302539800$

fax +31302537373

website www.koopmansinstitute.uu.nl

The Tjalling C. Koopmans Institute is the research institute and research school of Utrecht School of Economics.

It was founded in 2003, and named after Professor Tjalling C. Koopmans, Dutch-born Nobel Prize laureate in economics of 1975.

In the discussion papers series the Koopmans Institute publishes results of ongoing research for early dissemination of research results, and to enhance discussion with colleagues.

Please send any comments and suggestions on the Koopmans institute, or this series to J.M.vanDort@uu.nl

ontwerp voorblad: WRIK Utrecht

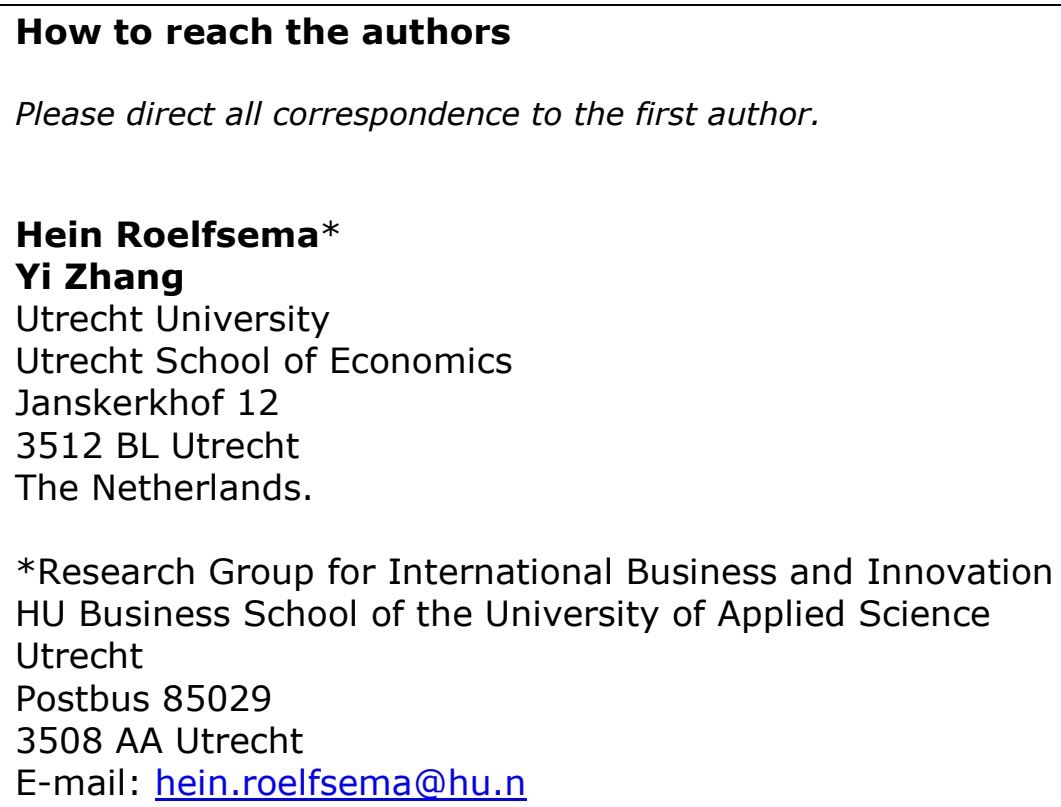


Utrecht School of Economics

Tjalling C. Koopmans Research Institute

Discussion Paper Series 10-05

\title{
Dual and common agency issues in international joint ventures: Evidence from
} China

\author{
Hein Roelfsemaa \\ Yi Zhang \\ aUtrecht School of Economics \\ Utrecht University \\ ${ }^{\mathrm{b}}$ Research Group for International Business and Innovation \\ HU Business School of the University of Applied Science Utrecht
}

March 2010

\begin{abstract}
With the help of a theoretical model we analyze the relation between equity sharing in an international joint venture (EJV) and local public goods provision in a setting where the local government faces a commitment problem to provide public services ex post to the set-up of the firm. We show that to overcome such a dual agency problem, the multinational leaves more local rents to the local partner than in the first-best, so as to provide stronger incentives for the government to supply public goods. Applying dynamic panel data estimation, we test the trade-off between local public goods and ownership shares across 31 Chinese provinces to find support for our mechanism
\end{abstract}

Keywords: Equity sharing, foreign investment, local public goods, China

JEL classification: F23, L14, L22, L23, O14 


\section{Introduction}

A key issue for multinational firms is the degree of authority over their foreign ventures. Clearly, full ownership makes the firm claimant on all of the foreign venture's profits. However, the transaction costs theory (Williamson 1985), the property rights literature (Grossman and Hart 1986; Hart and Moore 1990), as well as the managerial incentives literature (Holmstrom and Milgrom 1991) argues that when activities of the subsidiary's managers are imperfectly contractible, equity sharing reduces moral hazard and hold-up (Chi 1994; Pisano 1989). In addition, empirical research shows that sharing profits with local management stimulates innovation and makes them cooperate in transferring knowledge (for example Chen and Hennart 2004).

Another feature of equity joint ventures (EJV) is that profit sharing preserves incentives for government assistance, which adds to the institutional resource base of the joint venture (Parkhe 1993; Luo 2001). ${ }^{1}$ When local managers have a larger share in the joint venture, they are better motivated to act as linking pins between foreign investors and local government, so as to use their connections to improve the profitability of the venture (Shan 1991). In this spirit, Chari and Chang (2009) demonstrate that cultural distance between the home and host country has a positive effect on incentives for local managers. For China, Lee, Chen, and Kao (1998) show that when the local partner in the EJV is connected to the local government, the level of its equity ownership is higher. Moreover, many case studies on EJVs find a negative effect of foreign equity shares on local government involvement in creating the right business atmosphere (for example Prahalad and Hamel 1990; Luo 2001; Root 1988; Yan and Gray 1994).

In this paper, we study the relationship between equity shares and local public goods provision in China. We start by setting up a theoretical model to study how contracts between foreign and domestic partners deal with limited incentives for public officials. In a principal-agent relationship between the foreign investor (the principal) and the local partner (the agent), the local government acts as a dual agent whose ex post actions cannot be contracted directly. However, since the future revenues of the local private partner affect the government's incentives to provide

\footnotetext{
${ }^{1}$ In China, foreign direct investments (FDI) have moved from mainly equity joint ventures to predominantly fully owned foreign owned subsidiaries.
} 
public goods, in the venture stage leaving more rents to the local partner (partly) solves the commitment problem. We then extend the model to include free riding among foreign investors in a common agency setting and the effects of minimum local equity shares on profits and welfare. After that, we present empirical evidence for China on the interaction between local equity shares and public goods provision by applying dynamic panel estimation with two-stage least squares (2SLS) estimator. In line with our theoretical predictions on public incentives, infrastructural services across Chinese provinces increase with the level of local equity ownership in foreign funded enterprises (FFE). Moreover, a negative impact of the number of FFEs on local equity shares implies the presence of free riding, which is shown to exert a negative externality on public goods provision.

China is justified as an interesting case to study. First, China attracts much FDI, so we are able to observe dynamic effects. However, China has not fully transited into a market economy, so that the role of local government is important in attracting FDI. In addition, the large heterogeneity in the quality of local governments is suggested to be a critical determinant for equity sharing in EJV (Lee, Chen, and Kao 1998; Zhao and Zhu 1998), and has important effects on the geographical distribution of FDI across Chinese provinces (Cole, Elliott, and Zhang 2006; Cheung and Lin 2004; Fu 2008).

Government commitment is a common theme in the international trade literature, for example in setting tariffs and export taxes. Our paper is close to the spirit of Tirole (2003), who analyzes the commitment problem of governments in international finance. He shows that ex ante inefficient taxes on capital inflows may serve as an ex post efficient commitment devise for good domestic policies. His (and our) result echoes older and more general findings in the common agency literature that restrictions on the agent's behaviour may improve efficiency by alleviating the common pool problem, see for example Bernheim and Whinston (1997).

\section{The Theoretical Model}

Consider the unit production of a final good $z$ for which the price in the world market depends on the quality of the inputs. Production takes place in a partnership between a final goods producer and a specialized component producer. In line with most of the 
literature, suppose that there are two private inputs: the quality of headquarter services $h$ and that of the component $m$. In addition production needs a public input $a$ into the production process. We assume that the revenues of selling $z$ are $R=R(x)$ where $R(x)$ is the vector of inputs. $R(x)$ is strictly concave in all its arguments, all third derivatives are close to zero, and the inputs $m, h$, and $a$ are complementary to each other and that the mixed second-order derivatives $\left(R_{m h}, R_{m a}\right.$, and $\left.R_{h a}\right)$ are close to zero. ${ }^{2}$ The costs to supply quality of each input are captured by a convex cost function $C(x)$. Clearly, the first-best is a forcing contract on the quality of the inputs that maximizes profits $\Pi=$ $R(x)-\sum C(x)$ with the first-order conditions $R_{x}=C_{x}$.

\subsection{The basic model}

The set up of our model is an equity joint venture (EJV) where quality of the inputs is non-contractible so that incentives have to be provided. ${ }^{3}$ The foreign firm is the senior partner in the EJV and (as principal) has to decide on the equity (1- $\beta$ ) share it will take. Hence, the pay-offs for the foreign and the domestic firms in the EJV are:

$$
\begin{aligned}
& \Pi^{h}(m, h . a)=(1-\beta) R(m, h, a)-C(h) \\
& \Pi^{m}(m, h . a)=\beta R(m, h, a)-C(m)
\end{aligned}
$$

The local government's objective function maximizes the pay-off of the local supplier subject to the social costs of public investment:

$$
G=\beta R(m, h, a)-C(m)-C(a)
$$

\footnotetext{
${ }^{2}$ The same assumption is applied in Anderson (2009).

${ }^{3}$ There may be various reasons to consider this set up. For example, the quality depends on unobservable effort and cannot be verified before the final sale. Then, a contract cannot specify the quality of the input nor effort and relies on tying the rewards of the input producer to total revenues. It may also capture the case where there is some uncertainty in the contracting stage how high the price will be in the world market for a given quality. Also in that situation it may be optimal to design a bonus scheme that relates rewards of the input producer to the revenues in the world market when the input suppliers have observed the price-quality relation before they maximize profits. Further, when renegotiation is possible in the stage when the inputs have to be put together, then forcing contracts may simply not be credible. Lastly, forcing contracts may give rise to well-known multiple equilibria when financial sanctions are non-enforceable.
} 
The timing of events is as follows. In stage 1 the foreign partner in the EJV decides on the equity share $\beta$ for the local supplier; In stage 2 the government decides on the level of public investment $a$; In stage 3 the firms set production levels $h$ and $m$ and share the profits according to the equity shares. We solve for subgame-prefect equilibria. In stage 3, the firms choose $h$ and $m$. The first-order conditions for choosing the optimal quality of inputs are:

$$
\begin{aligned}
& (1-\beta) R_{h}(m, h, a)-C_{h}(h)=0 \\
& \beta R_{m}(m, h, a)-C_{m}(m)=0
\end{aligned}
$$

It is evident that both firms under invest in quality compared to the first-best, in line with Holmstrom (1982), who shows that in the absence of side-payments or third party enforcements first-best incentives cannot be implemented, since they break the budget constraint. We can show that $d m^{*} / d \beta>0, d h^{*} / d \beta<0$ and $d m^{*} / d a>0, d h^{*} / d a>0$, so that public investment may have a direct effect on revenues, but also increase the marginal returns to the private inputs. ${ }^{4}$

In stage 2, the government realizes that public investment will increase the revenues of both partners in the EJV, but it only cares for those of the local firm. Hence, it sets public investments to satisfy:

$$
d G / d a=\beta R_{a}\left(m^{*}, h^{*}, a^{*}\right)+\beta\left(d h^{*} / d a\right) R_{h}\left(m^{*}, h^{*}, a^{*}\right)-C_{a}=0
$$

When compared to the first-best public investment $R_{a}=C_{a}$, the first part of (6) indicates underinvestment in public goods when $\beta<1$. The second term shows that (to some extend) such weak incentives for public investment are mitigated by the fact that the government wants to induce higher investment from the foreign producer, so as to increase the profits of the local supplier. It is straightforward to show that $d a^{*} / d \beta$ $>0$, which means that increasing $\beta$ gives the local supplier a higher share in the profits and, hence, its government a stronger incentive to provide public goods. ${ }^{5}$

\footnotetext{
${ }^{4}$ Proofs in this paper are available upon request.

${ }^{5}$ An interesting side-result is that an unbiased social planner would conduct a higher level of public investment than the first-best level when the team structure of production provides too weak incentives for the firms. Such a social planner would maximize: $G=R(m, h, a)-C(m)-C(h)-C(a)$. As the
} 
In the first stage, there is a trade-off for the foreign firm. Increasing incentives for the component producer increases the supplier's quality of which he also benefits. However, these stronger incentives induce higher payment to the component supplier, which puts a dent in the profits of the final goods producer. In the first stage the final goods producer chooses incentives $\beta$ so as to maximize his own profits. The optimal $\beta$ maximizes equation (1), which (using the envelope theorem) gives:

$$
\begin{aligned}
& d \Pi^{h} / d \beta=-R\left(m^{*}, h^{*}, a^{*}\right)+\left(1-\beta^{*}\right)\left(d m^{*} / d \beta\right) R_{m}\left(m^{*}, h^{*}, a^{*}\right) \\
& +\left(1-\beta^{*}\right)\left(d a^{*} / d \beta\right) R_{a}\left(m^{*}, h^{*}, a^{*}\right)+\left(1-\beta^{*}\right)\left(d a^{*} / d \beta\right)\left(d m^{*} / d a\right) R_{m}\left(m^{*}, h^{*}, a^{*}\right)=0
\end{aligned}
$$

Equation (7) reveals that four arguments explain why the commitment problem forces incentives for the local supplier to be strong. Before we go over the arguments, recognize that investments in $m, h$, and $a$ are higher when no commitment problem is present and so are returns $R$. The first term of equation (7) shows that revenues $R$ are lower than in the absence of government commitment, so that giving incentives at the margin is less costly. By the second term, when the provision of $m, h$, and $a$ is lower due to the commitment problem, the marginal productivity of the local supplier is higher, which raises the rewards of providing incentives. The third term is positive and shows that the final goods producer has an incentive to push the government to increase public investment, which in turn increases the revenues of the foreign producer. Lastly, the fourth (positive) term reveals that more local rents further raise the investment of the local supplier through the increased public goods investment.

Intuitively, since the government only cares for the local supplier's benefits, leaving more rents to the local supplier also generates incentives for the local government to invest in public goods. The two-fold gains from stronger incentives for both the local supplier and government increase the total revenues and the payoffs to the foreign producer. Hence, when public goods are insufficient because of high opportunity costs, the foreign producer would like to stimulate public investment by giving the local supplier more rents. With some assumptions $\left(R_{m h}, R_{h m}, \beta^{2},(1-\beta)^{2}\right.$, and $\beta(1-\beta)$ are sufficiently small; both producers have the same revenues and costs

envelope theorem does not apply, this gives: $d G / d a=R_{a}-C_{a}+d m / d a\left(R_{m}-C_{m}\right)+d h / d a\left(R_{h}-C_{h}\right)=0$ Since the last two terms are positive, incentives for investing public goods may be higher than in the first-best case. 
structure $R_{m m}=R_{h h}=R_{a a}, C_{m m}=C_{h h}=C_{a a}$ ), solving for the optimal incentives in Equation (7) results in:

$$
\beta^{*}=\frac{R_{m}^{*}{ }^{2}+R_{a}^{*}{ }^{2}-R^{*}\left(C_{m m}-R_{m m}\right)}{R_{m}^{*}{ }_{m}{ }^{2}+R_{a}^{*}{ }^{2}-R^{*} R_{m m}}=1-\frac{C_{m m}-2 R_{m m}}{\left(R_{m}^{*}{ }^{2}+R_{a}^{*}{ }_{a}\right) / R^{*}-R_{m m}}
$$

Equation (8) implies some critical factors which determine the optimal rents left for the local partner. First, local equity shares increase when local intermediate inputs and public goods are more important for the joint production $\left(\partial \beta^{*} / \partial R_{m}>0, \partial \beta^{*} / \partial R_{a}>0\right)$. Second, with a concave revenues function, more local rents $\beta^{*}$ will be provided when the decreases of the marginal returns to local inputs ( $m$ or $a$ ) are smaller $\left(\partial \beta^{*} / \partial\left|R_{m m}\right|<0\right)$. Third, higher revenues mean a larger direct loss from sharing rents and therefore lead to weaker local incentives $\left(\partial \beta^{*} / \partial R^{*}<0\right)$. Government commitment results in larger marginal gains of local inputs $\left(R_{m}\right.$ and $\left.R_{a}\right)$ and lower revenues $\left(R^{*}\right)$, compared to the first-best case, and hence raises local rents.

\subsection{Free Riding}

From the perspective of country incentives, a common agency problem emerges. Actually, the common agency problem is a translation of the dual agency problem from the side of firms' managerial choices to the local government's behavior. Suppose that $N$ foreign firms engage in international team production. In this case the local government is a common agency of all production teams to provide non-rival and non-excludable public goods. The optimal level of public investment depends on the overall incentives offered by all firms. Yet, at least some foreign producers intend to provide weak incentives for the local suppliers, because they can free ride on public goods generated by other foreign producers' shared rents. When the local government only cares about local suppliers' benefits, however, it invests less in public goods given lowered local profits. In other words, common agency and free riding result in dual moral hazard of both the local government and the foreign firms, which cause under provision of public goods and under provision of incentives for the local firms. Negative externalities of common agency and free riding give rise to production efficiency loss. Therefore, when the public goods are so scarce, foreign firms have 
motivation to encourage the local government to improve the level of public investment.

Suppose that there are $N$ equity joint ventures. In stage 3 all EJVs choose the optimal levels of investments $m_{i}^{*}$ and $h_{i}^{*}$ given the incentive structure. In stage 2 the local government solves for the optimal level of public goods based on its objective function:

$$
\begin{aligned}
& G=\sum_{i=1}^{N} \beta_{i} R_{i}\left(m^{*}{ }_{i}, h^{*}, a\right)-\sum_{i=1}^{N} C_{i}\left(m^{*} i\right)-C(a) \\
& d G / d a=\sum_{i=1}^{N} \beta_{i}\left[R_{a^{i}}+\left(d h^{*}{ }_{i} / d a\right) R_{h^{i}}\right]-C_{a}=0
\end{aligned}
$$

Given the equity shares of other firms $\beta_{j}(j \neq i)$, the change of public investment with respect to individual local rents $\beta_{i}$ is:

$$
d a^{*} / d \beta_{i}=\left[R_{a}{ }^{i}+\left(d h^{*}{ }_{i} / d a\right) R_{h^{i}}\right] /\left(C_{a a}-\sum_{i=1}^{N} \beta_{i} R_{a a^{i}}\right)
$$

In stage 1 the foreign firms decide on their own local rents left for the local producers based on profits maximization:

$$
d \Pi^{h}{ }_{i} / d \beta_{i}=-R^{*}{ }_{i}+\left(1-\beta^{*}{ }_{i}\right)\left(d m^{*} / d \beta_{i}\right) R_{m^{i}}{ }^{i}+\left(1-\beta^{*}{ }_{i}\right)\left(d a^{*} / d \beta_{i}\right) R_{a^{i}}^{*}=0
$$

Imposing symmetry in equilibrium $\left(\beta^{*}{ }_{1}=\beta^{*}{ }_{2}=\cdots=\beta^{*}{ }_{N}\right.$ and $\left.\sum \beta^{*}{ }_{i}=N \beta^{*}{ }_{i}\right)$ and solving for optimal incentives with the same procedure in the single-firm case gives:

$$
\beta_{i}^{*}=1-\frac{R_{i}^{*}}{\left(d a^{*} / d \beta_{i}\right) R_{a^{i}}{ }^{i}\left(d m^{*} / d \beta_{i}\right) R_{m^{i}}^{*}}=\frac{R_{m}^{*}{ }^{2}+R_{a}^{*}{ }^{2}-R^{*}{ }_{i}\left(C_{m m}-R_{m m}\right)}{R_{m}^{*}{ }^{2}+R_{a}^{*}{ }_{a}-N R^{*} R_{m m}}
$$

In equation (13), $R_{m}^{*}$ represents the marginal returns to local inputs in the singe-firm case. Keeping other parameters constant, local shares decrease with the number of foreign investors when multinationals free ride on public incentives. This is an important result, because recent empirical research indicates that EJVs are replaced by 
fully foreign owned production facilities (Branstetter and Lardy 2007). The argument in this paper is that when the number of foreign firms in China increases, this gives the individual investor less incentive for profit sharing.

Totally differentiating equation (10) and applying symmetry in equilibrium, we find:

$$
\frac{d a}{d N}=\frac{\left.\left[R_{a^{i}}+\left(d h^{*} / d \beta_{i}\right) R_{h^{i}}\right)\right]}{C_{a a}-N \beta_{i} R_{a a^{i}}}\left[\beta_{i}+\left(d \beta_{i} / d N\right) N\right]
$$

Equation (14) represents the negative externalities from free riding. Local rents diminish with the opportunistic behaviour among foreign firms $\left(d \beta_{i} / d N<0\right)$, which in turn discourage the local government in public investment. Additionally, the positive second-order derivative of $a$ with respect to $N$ corresponds to a non-linear relation supported by the empirical evidence.

\subsection{Local Content Requirements}

When $N$ goes to infinity, no foreign firms give incentives for the local government so that the local government provides a minimum level of public goods. In this case leaving more local rents to encourage local public investment will increase the profits for both local and foreign producers. Compared to the total revenues with zero local public investment $\left(R_{i}^{*}=\left(1-\beta_{i}^{*}\right)\left(d m^{*}{ }_{i} / d \beta_{i}\right) R_{m^{i}}^{*}\right)$, revenues increase with local content requirements $\left(R^{L C}{ }_{i}>R^{*}{ }_{i}\right)$ under the condition below:

$$
\beta^{L C}<1-\frac{\left(1-\beta^{*}\right)\left(d m^{*}{ }_{i} / d \beta_{i}\right) R_{m^{i}}^{*}}{\left(d a^{L C} / d \beta^{L C}\right) R^{L C}{ }_{a^{i}}+\left(d m^{L C}{ }_{i} / d \beta^{L C}\right) R^{L C}{ }_{m^{i}}}
$$

Intuitively, when the local government realizes that foreign firms are free riding, it reduces local public investment. With many foreign investors and when public goods are very important for production, the request for local content requirements can increase the total revenues of the joint production and therefore the profits of foreign firms. 


\subsection{Hypotheses}

Based on this simple model, in the next section we test the following hypotheses:

H1: High levels of local ownership result in high levels of public goods.

H2: When levels of public goods increase, foreign firms have weaker incentives to leave rents to domestic firms.

H3: More foreign firms within a region results in free riding and, hence, in lower local ownership shares and lower level of public goods.

\section{Empirical Evidence}

To test the relation between equity sharing and public incentives, we use aggregated data for foreign funded enterprises (FFE) across 31 Chinese provinces between 1995 and 2006. Data are from Chinese Statistical Yearbook (1995-2007) published by the Chinese National Bureau of Statistics. Entry modes of multinationals in China can be classified into contractual joint ventures, cooperative ventures, and fully foreign funded enterprises. Equity sharing is captured by the ratio of local capital in total registered capital of FFE. In addition, we have data on the total number of FFEs and their investment level at provincial level. We measure local economic development by provincial GDP per capital and local public goods by a provincial infrastructural factor derived from variables on transportation and communication, which include length of city roads, area of city road, capacity of freight, length of railways, length of highways, length of inland waterways, capacity of telephone exchanges (longdistance, local, and mobile phone), and length of cable lines. Tables 1 and 2 present summary and correlation of level and first-differenced variables.

\subsection{Econometric Model}

The commitment problem can be formulated by the model below:

$$
\begin{gathered}
\text { Publicgoods } i t=\lambda_{1} \text { Publicgoods } i t-1_{-1}+\alpha_{1} \text { Localshares }_{i t}+\alpha_{2} \text { Localshares }_{i t-1}+ \\
\text { ONumberFFE } \\
\text { it }+\delta_{1} C V_{i t}+\delta_{2} C V_{i t-1}+\varepsilon_{i t}
\end{gathered}
$$




$$
\begin{aligned}
\text { Localshares }_{i t}= & \pi_{1} \text { Localshares }_{i t}-1+\pi_{2} \text { Localsharesit }-2_{2}+\gamma_{1} \text { Publicgoodsit }-1+ \\
& \gamma_{2} \text { Publicgoods } i t-2+\theta \text { NumberFFE }+\rho_{1} C V_{i t}+\rho_{2} C V_{i t-1}+v_{i t}
\end{aligned}
$$

The dependent variable in the econometric model [1] is the level of public goods represented by local infrastructure and $C V$ represents control variables. A dynamic setting is needed, since public goods provision is usually persistent over time. To account for autocorrelation, lag one is selected based on t-statistics. A positive $\alpha_{l}$ indicates that local governments invest more in infrastructure with more local shares, which therefore shows the presence of the commitment problem.

Model [2] illustrates a possible solution to the commitment problem when foreign investors take into account the role of local governments in equity sharing. To capture the dynamics of local rents, the optimal order of the lag length is selected to be two. Previous rather than the contemporary level of public goods is interesting because in equity sharing stage foreign investors are not acknowledged of the level of public goods ex post provided by local governments in our theoretical model. Hence, the existing level of public goods is used as a referenced baseline. If investors are satisfied with the existing level of infrastructure, zero $\gamma_{1}$ and $\gamma_{2}$ are expected because the commitment problem is not relevant in this case. However, if the accessible public goods are insufficient, negative $\gamma_{1}$ and $\gamma_{2}$ mean that foreign firms provide local rents to stimulate local governments in public investment.

Panel unit roots tests in Table 3 show that all the level variables are integrated at order one and first differencing yields stationary series. Meanwhile, first differencing helps to eliminate regional specific time-invariant characteristics. Therefore, the econometrics models are in first-differenced form. Since the firstdifferenced lagged dependent variables are endogenous by specification, lagged two level variables are used as instrumental variables, as proposed by Anderson and Hsiao (1981). 
Table 1

\section{Descriptive Statistics}

\begin{tabular}{|c|c|c|c|c|c|c|c|c|c|c|}
\hline \multirow[b]{2}{*}{ Variables } & \multicolumn{5}{|c|}{ Levels } & \multicolumn{5}{|c|}{ First Differences } \\
\hline & Obs. & Mean & Std. Dev. & Min & Max & Obs. & Mean & Std. Dev. & Min & Max \\
\hline Localshares & 369 & 0.3586 & 0.0978 & 0.1111 & 0.5524 & 338 & -0.0110 & 0.0456 & -0.1870 & 0.3333 \\
\hline Publicgoods & 371 & -0.0303 & 0.9896 & -1.3168 & 4.5063 & 340 & 0.0705 & 0.1711 & -0.5413 & 0.9982 \\
\hline GRPPC (In) & 369 & 8.9721 & 0.6709 & 7.3479 & 10.9629 & 338 & 0.1335 & 0.0982 & -0.1227 & 0.4880 \\
\hline FFE total investment (In) & 369 & 13.9207 & 1.5716 & 9.5670 & 17.2937 & 338 & 0.0937 & 0.4444 & -3.1559 & 3.3195 \\
\hline Number of FFE (1000 units) & 369 & 7.4813 & 11.1217 & 0.0510 & 61.9990 & 338 & 0.1104 & 1.0627 & -5.177 & 3.9340 \\
\hline
\end{tabular}

Table 2

Correlation

\begin{tabular}{|c|c|c|c|c|c|c|c|c|c|c|}
\hline \multirow[b]{2}{*}{ Variables } & \multicolumn{5}{|c|}{ Levels } & \multicolumn{5}{|c|}{ First Differences } \\
\hline & Localshares & Publicgoods & GRPPC & Investment & Number & Localshares & Publicgoods & GRPPC & Investment & Number \\
\hline Localshares & 1.0000 & & & & & 1.0000 & & & & \\
\hline Publicgoods & -0.3620 & 1.0000 & & & & -0.1016 & 1.0000 & & & \\
\hline GRPPC (In) & -0.6121 & 0.6218 & 1.0000 & & & 0.0420 & 0.0891 & 1.0000 & & \\
\hline investment (In) & -0.5628 & 0.7476 & 0.6877 & 1.0000 & & -0.1526 & 0.0628 & 0.0680 & 1.0000 & \\
\hline Number of FFE & -0.4692 & 0.7300 & 0.4943 & 0.7373 & 1.0000 & -0.0801 & 0.4179 & 0.1573 & 0.4028 & 1.0000 \\
\hline
\end{tabular}


Table 3

Panel Unit Root Tests

\begin{tabular}{lcccc} 
& \multicolumn{2}{c}{ Level } & \multicolumn{2}{c}{ First differences } \\
\hline Variables & $\mathrm{p}$-value & Order & $\mathrm{p}$-value & Order \\
\hline Localshares & 0.0000 & $\mathrm{I}(1)$ & 0.8298 & $\mathrm{I}(0)$ \\
Publicgoods & 0.0000 & $\mathrm{I}(1)$ & 0.3928 & $\mathrm{I}(0)$ \\
GRPPC (In) & 0.0000 & $\mathrm{I}(1)$ & 0.4534 & $\mathrm{I}(0)$ \\
FFE investment (In) & 0.0000 & $\mathrm{I}(1)$ & 0.9965 & $\mathrm{I}(0)$ \\
Number of FFE (In) & 0.0000 & $\mathrm{I}(1)$ & 0.9989 & $\mathrm{I}(0)$
\end{tabular}

Note: the null hypothesis of Hadrilm test (with Heteroskedastic error) is that all time series in the panel are stationary processes.

\subsection{Estimation Results}

The first four columns in Table 4 show the results of estimating the model [1]. Across panels, the impact of equity sharing on public goods provision is statistically significant positive. In the dynamic setting, local governments raise the infrastructural factor by 0.20 percentage points if foreign investors leave one percent more rents for their local partners. Regression results of the model [2] in Column (5) imply that foreign investors strategically respond to public goods provision. In provinces with one unit lower infrastructural factor, foreign investors share 4.9 percent more rents with local partners. When more public goods are needed (e.g. the level of the existing infrastructure is low), the results indicate that foreign investors deal with the commitment problem by offering stronger incentives. In addition, the significant negative impact of the number of FFEs on equity sharing suggests free riding among foreign investors.

The overall impact of the number of firms on public investment is shown in Column (1). When more FFEs are established, local governments expect more local rents, which act as incentives to supply public goods. Without raised local rents (keeping local rents constant), the benefits of involving more FDI are marginal. Therefore, a failure to realize the local governments' expectation results in weakened public incentives. More importantly, free riding reduces public incentives and therefore leads to an indirect effect of the number of FFEs on public goods through lower equity sharing. The specific effect of free riding is obtained by comparing results in Columns (1) and (3). If we control for local shares in Column (3), the 
difference between the magnitudes of the number of FFEs variable in Columns (1) and (3) can be viewed as the effect free riding on public incentives.

Furthermore, a turning point of increasing investing firms is supported by the positive squared terms in Columns (2) and (4). The negative externalities of free riding can be internalized when foreign investors realize the efficiency loss and increase local rents. When the level of public goods hits the bottom due to free riding, at least some of the foreign investors may stand out to alleviate the inefficiency. Alternatively, local governments may exert local content requirements. With a minimum amount of local rents requested, foreign investors have obligation in sharing profits with local partners.

Table 4

Dynamic Panel Estimation Results (2SLS)

\begin{tabular}{|c|c|c|c|c|c|}
\hline & \multicolumn{4}{|c|}{ Model [1] } & \multirow{2}{*}{$\begin{array}{c}\text { Model [2] } \\
(5)\end{array}$} \\
\hline Variables & $(1)$ & (2) & (3) & (4) & \\
\hline$\Delta$ Publicgoods $_{-1}$ & $\begin{array}{r}0.952^{\star \star \star} \\
(0.108)\end{array}$ & $\begin{array}{r}0.937^{\star \star \star} \\
(0.108)\end{array}$ & $\begin{array}{r}0.955^{\star \star \star} \\
(0.108)\end{array}$ & $\begin{array}{r}0.941^{\star \star \star} \\
(0.108)\end{array}$ & $\begin{array}{r}0.012 \\
(0.025)\end{array}$ \\
\hline$\Delta$ Publicgoods $_{-2}$ & & & & & $\begin{array}{l}-0.044^{*} \\
(0.024)\end{array}$ \\
\hline$\Delta$ Localshares & & & $\begin{array}{c}0.209^{*} \\
(0.118)\end{array}$ & $\begin{array}{r}0.200^{*} \\
(0.117)\end{array}$ & \\
\hline$\Delta$ Localshares $_{-1}$ & & & $\begin{array}{r}0.042 \\
(0.144)\end{array}$ & $\begin{array}{r}0.035 \\
(0.143)\end{array}$ & $\begin{array}{r}0.174 \\
(0.333)\end{array}$ \\
\hline$\Delta$ Localshares $_{-2}$ & & & & & $\begin{array}{r}0.099 \\
(0.167)\end{array}$ \\
\hline Number of FFEs (In) & $\begin{array}{r}-0.071^{\star *} \\
(0.029)\end{array}$ & $\begin{array}{r}-0.045 \\
(0.041)\end{array}$ & $\begin{array}{r}-0.062^{\star \star} \\
(0.027)\end{array}$ & $\begin{array}{r}-0.038 \\
(0.039)\end{array}$ & $\begin{array}{l}-0.102^{\star} \\
(0.060)\end{array}$ \\
\hline$\Delta$ Number squared & & $\begin{array}{r}0.013 \\
(0.010)\end{array}$ & & $\begin{array}{r}0.012 \\
(0.009)\end{array}$ & \\
\hline$\triangle G R P P C(\ln )$ & $\begin{array}{l}0.338^{* *} \\
(0.145)\end{array}$ & $\begin{array}{l}0.340^{\star *} \\
(0.146)\end{array}$ & $\begin{array}{l}0.336^{\star *} \\
(0.147)\end{array}$ & $\begin{array}{l}0.338^{\star *} \\
(0.148)\end{array}$ & $\begin{array}{r}0.039 \\
(0.039)\end{array}$ \\
\hline$\triangle G R P P C_{-1}$ & $\begin{array}{l}-0.065 \\
(0.167)\end{array}$ & $\begin{array}{r}-0.060 \\
(0.166)\end{array}$ & $\begin{array}{r}-0.069 \\
(0.170)\end{array}$ & $\begin{array}{r}-0.064 \\
(0.169)\end{array}$ & $\begin{array}{l}-0.013 \\
(0.052)\end{array}$ \\
\hline$\Delta$ Investment (In) & $\begin{array}{r}0.092^{\star \star \star *} \\
(0.029)\end{array}$ & $\begin{array}{l}0.078^{* *} \\
(0.032)\end{array}$ & $\begin{array}{r}0.087^{\star \star \star *} \\
(0.028)\end{array}$ & $\begin{array}{l}0.075^{\star *} \\
(0.031)\end{array}$ & $\begin{array}{r}0.046 \\
(0.055)\end{array}$ \\
\hline$\Delta$ linvestment $_{-1}$ & $\begin{array}{r}-0.006 \\
(0.010)\end{array}$ & $\begin{array}{r}-0.011 \\
(0.010)\end{array}$ & $\begin{array}{r}-0.004 \\
(0.011)\end{array}$ & $\begin{array}{r}-0.009 \\
(0.010)\end{array}$ & $\begin{array}{r}-0.011 \\
(0.012)\end{array}$ \\
\hline IV first-stage ( $p$-value) & 0.0000 & 0.0000 & 0.0000 & 0.0000 & 0.0063 \\
\hline Test HO: Exogeneity & 0.0000 & 0.0000 & 0.0000 & 0.0000 & 0.0000 \\
\hline Joint significance & & 0.0047 & & 0.0044 & \\
\hline No. of observations & 308 & 308 & 308 & 308 & 276 \\
\hline
\end{tabular}

Note: Standard deviation in parentheses. Significance level $1 \% * * *, 5 \% * *$, and $10 \% *$. Regression controls for year dummy. Since provinces may interact with each other, standard errors are corrected for cross-provincial (spatial) and temporal dependence. Robustness tests show that contemporary variable is insignificant in column (5). 


\section{Concluding Comments}

This paper has investigated the dual and common agency problems in international investment strategies of multinational firms. So far, papers that discuss the interaction between the headquarter firm and the production facility have taken government behaviour as given. This is an important omission, since the role of the (local) government is a potential critical source of the contract imperfection. We model such a contract imperfection explicitly by introducing a dual agency problem. We show that the headquarter firm may leave more rents for the production facility's management to induce its government to behave well. Although it is difficult to isolate these effects in a macro-political environment, we do present some evidence for China on the trade-off between foreign rents and local government incentives.

By endogenizing government behaviour we may speculate on an additional set of results when the model is slightly enriched. First, we have set up the model in the managerial incentives tradition, which highlights the moral hazard problem in production. Alternatively, we may consider a set up where re-negotiation takes place after the initial production stage. We are confident that such a set up would not alter the basic intuitions presented in the present paper. Moreover, is such a setting we may model government effort as enforcement of private contracts. In that case an intriguing result arises in that the local government may strategically under invest in the rule of law, so as to induce higher rents for the domestic firm.

What we have not done is to make the now standard connection to the literature on firm heterogeneity. As is well known, differences in firm productivity may cause differences in internationalization strategy. Clearly, taking up government incentives may affect the choice over FDI or outsourcing. To speculate, it may well be that the dual agency problem inflicts a bias towards outsourcing. The reason is that outsourcing contracts - in contrast to FDI - can easily be cancelled in the short run, so that they discipline the government in providing public goods.

Our model on equity sharing may also capture the incentives brought about by knowledge sharing and knowledge transfer EJVs. Often, local government is more interested in such transfers than in profits of local firms. For example, to take advantage of low labour costs, Advanced Micro Devices (AMD) has set up various 
production plants across China. In order to get government supports in local production, AMD has an interest in maintaining a good relationship with the Chinese government. This means that AMD sometimes has to do things which may run against its short run interest. As a case in point, with respect to AMD's research cooperation with one Chinese local computer chip producer, an AMD general manager points out: "This is a potential competitor for AMD, but we are still doing that... This is the commitment of AMD to the Chinese government. If you want to do business here in China, you have to grow with China together”.

Lastly, our discussion on local content requirements may open up to a broader discussion on the merit if trade barriers. For example, Ornelas and Turner (2008) investigate the effects of trade protection when firms enter in imperfect contracts. They show that when tariffs increase the rewards to domestic factors of production, they may also raise the rents to domestic firms in vertical relationships, and for that reason may increase social welfare. For this reason, in our set up a government may strategically raise trade barriers so as to credibly commit to good policies and hence higher income for domestic workers. 


\section{References}

Anderson, James. “Does Trade Foster Contract Enforcement?” Economic Theory, 41 (2009): 105-130.

Anderson, T.W., and C. Hsiao. "Estimation of dynamic models with error components.” Journal of the American Statistical Association, 76 (1981): 589606.

Antrás, Pol. "Firms, Contracts, and Trade Structure." The Quarterly Journal of Economics, 118 (2003): 1375-1418.

Bagwell, K., and R.W. Staiger. "Domestic Policies, National Sovereignty, and International Economic Institutions.” Quarterly Journal of Economics, 116 (2006): 519-562.

Bernheim, B.D., and M.D. Whinston. “Common Agency.” Econometrica, 54 (1986): 923-942.

Branstetter, L., and N. Lardy. "China's Embrace of Globalization.” pp 633-682 in Brandt, L., and T. Rawski, ed. China's Great Economic Transformation. Cambridge: Cambridge University Press, 2008.

Chari, M.DR., and K.Y. Chang. "Determinants of the Share of Equity Sought in Cross-border Acquisitions." Journal of International Business Studies, 40 (2009): 1277-1297.

Chen, S., and J.F. Hennart. "A Hostage Theory of Joint Ventures: Why do Japanese Investors Choose Partial over Full Acquisitions to Enter the United States?” Journal of Business Research, 57 (2004): 1126-1134.

Cheung, K.Y., and P. Lin. "Spillover Effects of FDI on Innovation in China: Evidence from the Provincial Data.” China Economic Review, 15 (2004): 25-44.

Chi, Tailan. "Trading in Strategic Resources: Necessary Conditions, Transaction Cost Problems, and Choice of Exchange Structure.” Strategic Management Journal, 15 (1994): 271-290.

Cole, M., R. Elliott, and J. Zhang. "Corruption, Governance and FDI Location in China: A Province-Level Analysis.” Department of Economics, University of Birmingham, 2006.

Fan, G., X. Wang, and H. Zhu. NERI index of Marketisation for China's Provinces: 2006 report (in Chinese). Beijing: Economic Science Press, 2007.

$\mathrm{Fu}$, Xiaolan. "Foreign Direct Investment, Absorptive Capacity and Regional Innovation Capabilities: Evidence from China.” Oxford Development Studies, 36 (2008): 89-110.

Grossman, S.J., and O.D. Hart. "The Costs and Benefits of Ownership: A Theory of Vertical and Lateral Integration.” The Journal of Political Economy, 94 (1986): 691-719.

Hart, O., and J. Moore. "Property Rights and the Nature of the Firm." The Journal of Political Economy, 98 (1990): 1119-1158.

Helpman, Elhanan. "Trade, FDI, and the Organization of Firms." Journal of Economic Literature, 44 (2006): 589-630.

Holmstrom, Bengt. "Moral Hazard in Teams.” The Bell Journal of Economics, 13 (1982): 324-340.

Holmstrom, B., and P. Milgrom. "Multitask Principal-Agent Analyses: Incentive Contracts, Asset Ownership, and Job Design.” Journal of Law, Economics, and Organization, 7 (1991): 24-52. 
Lee, J.R., W.R. Chen, and C. Kao, "Bargaining Power and the Trade-off between the Ownership and Control of International Joint Ventures in China.” Journal of International Management, 4 (1998): 353-385.

Luo, Yadong. "Equity Sharing in International Joint Ventures: An Empirical Analysis of Strategic and Environmental Determinants." Journal of International Management, 7 (2001): 31-58.

National Bureau of Statistics of China. China Statistical Yearbook (1995-2007). Beijing: China Statistical Press, 1995-2007.

Ornelas, E., and J.L. Turner. "Protection and International Sourcing." Centre for Economic Performance, LSE, 2008.

Parkhe, Arvind. "Strategic Alliance Structuring: A Game Theoretic and Transaction Cost Examination of Interfirm Cooperation.” The Academy of Management Journal, 36 (1993): 794-829.

Pisano, Gary P. "Using Equity Participation to Support Exchange: Evidence from the Biotechnology Industry.” Journal of Law, Economics, and Organization, 5 (1989): 109-126.

Prahalad, C.K., and G. Hamel. "The Core Competence of the Corporation.” Harvard Business Review, 66 (1990): 79-91.

Root, Franklin R. "Environmental Risks and the Bargaining Power of Multinational Corporations.” The International Trade Journal: Western Hemispheric Studies, 3 (1988): 111-124.

Shan, Weijian. "Environmental Risks and Joint Venture Sharing Arrangements." Journal of International Business Studies, 22, (1991): 555-578.

Tirole, Jean. "Inefficient Foreign Borrowing: A Dual- and Common-Agency Perspective.” The American Economic Review, 93 (2003): 1678-1702.

Williamson, Oliver E. "Transaction-Cost Economics: The Governance of Contractual Relations.” The Journal of Law and Economics, 22 (1979): 233.

Yan, A.M., and B. Gray. "Bargaining Power, Management Control, and Performance in United States-China Joint Ventures: A Comparative Case Study." The Academy of Management Journal, 37 (1994): 1478-1517.

Zhao, H.X., and G.T. Zhu. "Determinants of Ownership Preference of International Joint Ventures: New Evidence from Chinese Manufacturing Industries.” International Business Review, 7 (1998): 569-5. 